\title{
Render Unto Rawls: Law, Gospel, and the Evangelical Fallacy
}

Wayne R. Barnes

Texas A\&M University School of Law, wbarnes@law.tamu.edu

Follow this and additional works at: https://scholarship.law.tamu.edu/facscholar

Part of the Law and Politics Commons, and the Law and Society Commons

\section{Recommended Citation}

Wayne R. Barnes, Render Unto Rawls: Law, Gospel, and the Evangelical Fallacy, 24 U. Fla. J.L. \& Pub. Pol'y 235 (2013).

Available at: https://scholarship.law.tamu.edu/facscholar/308

This Article is brought to you for free and open access by Texas A\&M Law Scholarship. It has been accepted for inclusion in Faculty Scholarship by an authorized administrator of Texas A\&M Law Scholarship. For more information, please contact aretteen@law.tamu.edu. 


\title{
RENDER UNTO RAWLS: LAW, GOSPEL, AND THE EVANGELICAL FALLACY
}

\author{
Wayne R. Barnes*
}

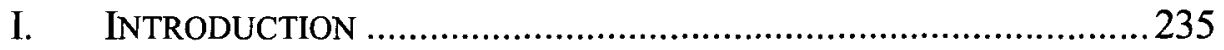

II. Christian Political ARguments vs. Rawlsian

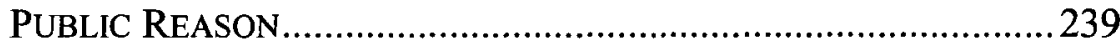

III. ThE EVANGelical Christian GosPeL:

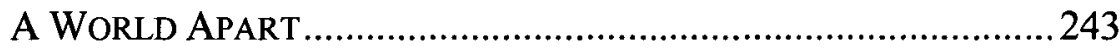

A. The Explicit Christian Gospel: Faith Alone ........................246

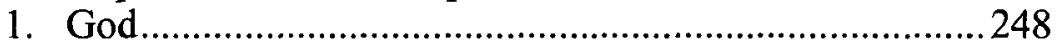

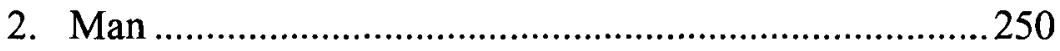

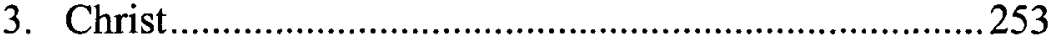

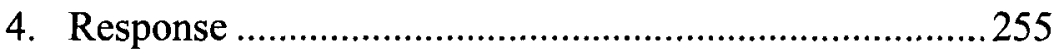

B. The Mistake of Works-Based Moralism .............................257

C. Christian Political Argumentation =

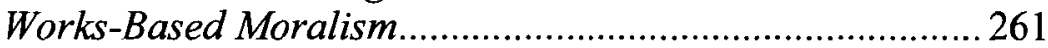

D. Two Corroborating Observations.........................................2265

1. The Infeasibility of Codifying all Christian Moral Precepts ............................................................265

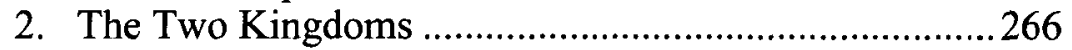

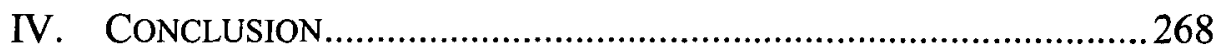

\section{INTRODUCTION}

Many explicitly Christian voices inject themselves frequently and regularly into the current public policy and political discourse. Though not all, many of these Christian arguments proceed in something like the following manner: $\mathrm{X}$ is condemned (or required) by God, as revealed in the Bible. Therefore, the explicitly-required "Christian position" on $\mathrm{X}$ is for the law to prohibit or limit the activity (or require

* Professor, Texas A\&M University School of Law. Thanks to my colleagues at Texas A\&M for helpful comments at a faculty colloquium during the Spring 2013 semester, and further thanks to the participants of the Love and Law Conference held at Pepperdine University School of Law on February 7-8, 2014. Finally, I wish to thank Professor Samuel Calhoun for extremely generous giving of his time and effort in reviewing a prior draft of this Article, and for stimulating and challenging my thinking greatly on this subject. 
it), in accordance with the advocate's interpretation of biblical ethical standards. To be clear, I mean to discuss only those scenarios where a Christian publicly identifies a position as being mandated by Christian morality or values (i.e., where the public is given a message that some law or public policy is needed in order to comply with Christian scriptures or God's will). That is, in short, this Article is about explicit political communications to the public in overt religious language of what Christianity supposedly requires for law and policy. As will be seen, these voices come quite famously from the Christian Religious Right, but they come from the Religious Left as well.

Political philosophers (most famously John Rawls) have posited that pluralism and principles of liberal democracy strongly counsel against resort to such religious views in support of or against any law or public policy. ${ }^{1}$ That is, in opposition to this overt religious advocacy in the political realm (though, it should be noted, not necessarily taking a substantive position on the issues, per se) is the position of Rawlsian political liberalism, which states generally that, all things being equal, such inaccessible religious arguments should not be made, but rather arguments should only be made by resort to "public reason" which all find to be accessible. ${ }^{2}$ Christian political voices counter that this results in an intolerable stifling of their voice, of requiring that they "bracket" their religious views from the public square, ${ }^{3}$ and indeed results in the complete trivialization of their religious voice in the public square. ${ }^{4}$

But there is something I am interested in which has largely evaded discussion. Advocates of the "values" position for law, or the "Christian" position or the "biblical" position I have described herein, are arguably communicating something theological to the public when they so advocate, and not just political. As Cass Sunstein and others have noted, actions have meanings, including laws and advocacy therefor. ${ }^{5}$ This is no less true when Christian advocates seek to persuade the public to enact a law that will be enforceable against everyone regardless of religious belief. I believe, at least in part, the message unavoidably communicated is that, "One must vote for and/or comply with this advocated law in order to comply with 'Christian' behavioral standards of morality, and thus, presumably, to gain greater favor with

1. John Rawls, Political Liberalism 212-54 (1993) (discussing public reason); see also John Rawls, The Idea of Public Reason Revisited, 64 UnIV. OF CHI. L. REV. 765 (1997).

2. See RAWLS, supra note 1.

3. See, e.g., David M. Smolin, Regulating Religious and Cultural Conflict in a Postmodern America: A Response to Professor Perry, 76 IoWA L. REv. 1067 (1991).

4. See Stephen L. Carter, The Culture of Disbelief: How American law and Politics Trivialize Religious Devotion (1993). (1996).

5. See Cass R. Sunstein, On the Expressive Function of Law, 144 U. PENN. L. REV. 2021 
God." That this is being communicated does not seem to be seriously questioned, either by those who advocate such "values" or "Christian" legal positions, or by the Rawlsian liberals who plead for restraint from such religious advocacy. All sides of the debate seem to share the underlying premise that the "Christian/values" argument for law and policy is communicating-whether from the perspective of the Religious Right or the Religious Left-that compliance with its policy articulations will result in greater favor with God.

This is as tragic as it is mistaken.

I bring my voice to this issue not primarily as a political philosopher, nor a constitutional expert, nor a professional theologian, but as a citizen and a legal academic who also happens to be an evangelical Christian. Although the chorus of voices from the right and left who bring their religious views to bear on political and legal issues in public discourse arises from a variety of religious perspectives, it seems that a great many of them come from various evangelical Christian groups loosely comprising what has come to be known as the Religious Right and Religious Left, respectively. It is these voices I wish to counter for I believe that the theological message that their political advocacy communicates-whether intended or merely incidental-is fundamentally at odds with the actual, central Christian message of the Gospel. The fundamental message of the Gospel, held nearly universally by Protestant, evangelical Christians who highly regard scripture as revealed in the Bible is this: Mankind as a species is broken and in conflict with God because of our sinful nature. Although God has revealed the level of conduct and behavior that He requires, none of us can actually comply and please God by our behavior alone-that is, by "works." Rather, the means of salvation that God has provided comes in the form of the person of Jesus Christ, and His sacrificial death and resurrection. ${ }^{9}$ Evangelical Christians believe that it is only when a person acknowledges his sinful nature, realizes that Christ's death was necessary and on his behalf, and turns to God and repentsthat is, by "faith" - that salvation is achieved, and reconciliation with

6. See infra notes 14-33 and accompanying text.

7. See Romans 3:23 (ESV) ("All have sinned and fall short of the glory of God."); see also JOHN R.W. STOTT, BASIC CHRISTIANITY 61-80 (2d ed. 1971) (discussing the fact and nature of sin, as well as the consequences of sin); THE WESTMINSTER CONFESSION OF FAITH, ch. VI (1646), available at www.reformed.org/documents/wcf_with_proofs/index.html) (last visited Dec. 11, 2012).

8. Ephesians $2: 8$ (ESV) ("For by grace you have been saved through faith. This is not your own doing; it is the gift of God."); see also THE WESTMINSTER CONFESSION OF FAITH, supra note 7, ch. XI ("Faith, thus receiving and resting on Christ and His righteousness, is the alone instrument of justification.").

9. See STOTT, supra note 7, at 81-106 (discussing the death and salvation of Christ). 
God can occur. ${ }^{10}$

The issue is significant. We evangelical Christians, on Sundays, profess and believe that salvation and favor with God is obtained by faith in Christ alone. No amount of works, or behavior, will suffice. But on Mondays, these same evangelical Christians will put on their political hats and proclaim that we need to get God back in the public square, return to our status as a "Christian nation" and enact laws that reflect our "Christian values." But law is inherently coercive, and is thus focused only on behavior. ${ }^{11}$ Seemingly forgetting everything we learned on Sunday, we proclaim on Monday that favor with God can be obtained by Christians and non-Christians alike (for the law of the land applies to all citizens) if they will only comply with state-sanctioned, coercive laws promulgated and advocated for in the name of "Christian principles" or "traditional family values." Simply put, on Sundays we proclaim (correctly) that favor with God is obtained by faith. But on Mondays we proclaim (incorrectly) that favor with God can somehow be obtained by works. This causes me, as an evangelical Christian, genuine concern for the souls of this country, and frustration with my fellow evangelical Christians for the incorrect message they are sending about our faith.

If I am correct, evangelical Christians on the Religious Right and Left should take a different course. John Rawls's theory of political liberalism and public reason is not necessarily the harbinger of apocalyptic doom that some Christians suppose. In fact, Christian political advocates would do well to adhere to his prescription for public reason in political and legal debates. The reasons are practical as well as spiritual. The practical reasons are well known: religious arguments are inaccessible to those who do not share the underlying beliefs in the transcendent and the divine, ${ }^{12}$ they will be unpersuasive to those who do not share the belief anyway, and such argument is ultimately disrespectful to non-believing citizens in a pluralistic, liberal democracy. ${ }^{13}$ But I here inject the spiritual reasons as well-coercive law has no place in the Christian witness to the nation and the world, for

10. Romans 10:9-11 (ESV).

[I] $\mathrm{f}$ you confess with your mouth that Jesus is Lord and believe in your heart that God raised him from the dead, you will be saved. For with the heart one believes and is justified, and with the mouth one confesses and is saved. For the Scripture says, "Everyone who believes in him will not be put to shame."

Id.; see also THE WESTMINSTER CONFESSION OF FAITH, supra note 7, ch. XI.

11. See Ekow N. Yankah, The Force of Law: The Role of Coercion in Legal Norms, 42 U. RICH. L. REV. 1195 (2008).

12. See RAWLS, supra note 1.

13. Christopher J. Eberle, Religious Conviction in Liberal Politics 84-108 (2002). 
such a message communicates that favor with God can be obtained by works, when in fact faith alone is the only way we believe that reconciliation with God can occur for man.

Part II of this Article will briefly discuss Christian political arguments in this country and their expressive effect, while also addressing how such arguments are in conflict with Rawlsian ideals of public reason. Part III will set forth the explicit Christian gospel message and show that adhering to it accurately coheres better to Rawlsian ideals of public reason for law than the typical Christian political argumentation. Part IV will offer a brief conclusion.

\section{Christian Political Arguments vs. Rawlsian Public ReAson}

In this Part, I will observe the typical types of Christian political argumentation made in American politics today and also analyze their expressive effects. Rawlsian ideals of public reason will next be summarized, to set up the conflict between the two modes of political advocacy.

Christian political advocates make arguments from both the conservative and liberal end of the ideological spectrum. The conservative advocates tend to be known as the "Religious Right." As James Davison Hunter has noted, conservative Christians are concerned with issues of sexuality, marriage, and the sanctity of human life. ${ }^{14}$ They seek to "preserve, protect and defend the Judeo-Christian values that have made this the greatest country in history." "An oft-stated goal is to return to a "Christian America."16 Pat Buchanan, in his speech to the 1992 Republican Convention, proclaimed that " $[\mathrm{t}]$ here is a religious war going on in this country. It is a cultural war ... for the soul of America." ${ }^{17}$ A couple of the more well-known advocates within the Religious Right are Pat Robertson and the late Jerry Falwell. As recently as the closing days of the 2012 Presidential election, Billy Graham took out a full-page ad in several national newspapers exhorting voters to vote for "biblical principles"18 and Mike Huckabee

14. James Davison Hunter, To Change the World: The Irony, Tragedy, and POSSIBILITY OF ChRISTIANITY IN THE LATE MODERN WORLD 111 (2010).

15. Id. at 126 (citing CHRISTLAN COALITION, www.cc.org/vision.cfm (last visited Jan. 25 , 2008)).

16. Id. at 127 .

17. Patrick J. Buchanan, Address to the Republican National Convention in Houston, Texas (Aug. 17, 1992), http://www.americanrhetoric.com/speeches/patrickbuchanan $1992 \mathrm{mc}$. htm (emphasis added).

18. David Ward, Billy Graham Political Newspaper Ad Campaign: 'Vote for Biblical Values,' DESERET NEws (Nov. 1, 2012, 1:51 AM), http://www.deseretnews.com/article/865565 
warned voters to vote the values that would "stand the test of fire.,"19 Dozens of other examples of organizations overtly advocating for "Christian principles" in law and policy could be given. ${ }^{20}$

Just as there are Christians on the Religious Right making public political arguments for law and policy in line with a religious perspective, Christians on what may be termed the "Religious Left" make similar arguments. According to James Davison Hunter, whereas the Religious Right is largely defined by behavioral morality and values, "progressives have always been animated by the myth of equality and community and therefore see history as an ongoing struggle to realize these ideals." 21 More specifically, "[t]he biblical tradition that Christian progressives appeal to is the prophetic tradition in its condemnation of the wealthy for their abuse of the poor, the weak, and the marginalized."22 Martin Luther King, Jr. was one famous Christian advocate from the Left, by virtue of his explicit Christian appeals as a central part of his civil rights efforts. ${ }^{23}$ In the current day, some examples of prominent members of the Religious Left include a new group of influential, progressive evangelical Christians, including Jim Wallis, John Perkins, Sharon Gallagher, Brian McLaren, and Randall Balmer. ${ }^{24}$ The Religious Left movement memorably spoke out during the 2004 election with a full-page ad in the New York Times and other newspapers titled "God is not a Republican . . or a Democrat." 25 Jim Wallis is the leader of an organization called Sojourners, whose stated mission is "to articulate the biblical call to social justice, inspiring hope and building a movement to transform individuals, communities, the church and the world." ${ }^{26}$ In another ad, Sojourners joined with other organizations to publish a full-page ad during budget negotiations in Congress entitled "What Would Jesus Cut?"27 Many other people and organizations engage in similar Christian left political advocacy. ${ }^{28}$

802/Billy-Graham-ad-Vote-for-biblical-values.html?pg=all.

19. R. Duane Graham, Did Mike Huckabee Really Say That You Will Go to Hell if You Vote for Obama?, ERSTWHILE CONSERVATIVE (Oct. 31, 2012), at hitp://duanegraham.wordpress. com/2012/10/31/did-mike-huckabee-really-say-that-you-will-go-to-hell-if-you-vote-for-obama/.

20. HUNTER, supra note 14, at 122.

21. Id. at 132 .

22. Id. at 133 .

23. STEPHEN L. CARTER, God's NAME IN VAIN: THE WRONGS AND RIGHTS OF RELIGION IN Politics 20 (2000).

24. HUNTER, supra note 14 , at 137.

25. Id.

26. See Mission Statement, SOJOURNERS, http://sojo.net/about-us/mission-statement (last visited Dec. 14, 2012).

27. Jim Wallis, What Would Jesus Cut?, SOJOURNERS (May 2011), http://sojo.net/magaz ine/2011/05/what-would-jesus-cut.

28. HUNTER, supra note 14 , at 138-47. 
All actions are expressive, as Cass Sunstein has noted. ${ }^{29}$ As Sunstein pointed out in his 1996 article, On the Expressive Function of Law, "[w]hat can be said for actions can also be said for law." evangelical Christian, I have been motivated to write this Article based on the expression that I believe occurs when my fellow evangelical Christians engage in the type of political argumentation described in this Part. The message I believe that is being conveyed by both the Religious Right and Left is an inevitable result from the mixture of law and religion, and more specifically law and Christianity, into a single message of political advocacy. By "law," the advocates mean the binding body of rules governing the citizenry. Law is of course inherently coercive and focused only on behavior. ${ }^{31}$ By "Christian," the advocates refer to the tenets of the Christian religion, whose major ideal is obtaining a proper relationship with God, divine favor, and ultimately, redemption and salvation for one's soul. ${ }^{32}$ Therefore, a plausible interpretation of these messages is this: if I behave according to the proposed "Christian" legal principles being advocated, I will obtain greater favor with God. ${ }^{33}$ Put more simply, good behavior equals divine favor.

Largely in opposition to the overt Christian and religious argumentation of both the Religious Right and Left stand the ideals of Rawlsian public reason. In John Rawls's 1993 book Political Liberalism, Rawls in part took up the issue of the "problem of political liberalism," which he says is: "How is it possible that there may exist over time a stable and just society of free and equal citizens profoundly divided by reasonable religious, philosophical, and moral doctrines?"34 For the religious (including Christian) adherent, Rawls put the question even more sharply: "How is it possible for those affirming a religious doctrine that is based on religious authority, for example, the church or the Bible, also to hold a reasonable political conception that supports a just democratic regime?" ${ }^{35}$ The democratic goal to which Rawls aspires

29. Sunstein, supra note 5, at 2021.

30. Id. at 2022 (emphasis added).

31. See Yankah, supra note 11.

32. See, e.g., RAWLS, supra note 1 , at $\mathrm{xxi}$, xxiii (describing Christianity as being a "religion of salvation").

33. This interpretation was vividly illustrated, at least with respect to the Huckabee ad referenced earlier, in The Daily Show's Jon Stewart's reaction to the ad: "I would say it is not an unreasonable interpretation of that commercial that if you vote for gay marriage or for a prochoice candidate, God is writing it down, and he gon' getcha." Jessica Bluemke, Mike Huckabee Defends Christian Campaign Ad on 'The Daily Show,' Patheos.com (Nov. 13, 2012), http://www.patheos.com/blogs/friendlyatheist/2012/11/13/mike-huckabee-defends-christian-ca mpaign-ad-on-the-daily-show/.

34. See RAWLS, supra note 1 , at xxv.

35. Leslie Griffin, Good Catholics Should be Rawlsian Liberals, 5 S. CAL. INTERDISC. L.J. 297, 299 (1997) (citing JOHN RAWLS, POLITICAL LIBERALISM xxxix (paper ed. 1996) 
is that of an "overlapping consensus" as to matters of justice and public policy. Thus, he envisions citizens who adhere to different comprehensive doctrines of truth and yet jointly consent to law and policy formulations based on points of discovered commonality. ${ }^{36}$ The key to Rawls's hope to achieve the overlapping consensus is the use by all citizens of public reason in democratic deliberations and advocacy. As Leslie Griffin explained Rawls's reasoning:

It "means that in discussing constitutional essentials and matters of basic justice we are not to appeal to comprehensive religious and philosophical doctrines---to what we as individuals or members of associations see as the whole truth.... Instead, public reasoning should rest on more "widely accepted, or available"" arguments. "[E]ach of us must have, and be ready to explain, a criterion of what principles and guidelines we think other citizens (who are also free and equal) may reasonably be expected to endorse along with us.",37

The Rawlsian approach to public reason and a pluralistic conception of the common good has been widely, if not universally, accepted, and has had many notable public adherents, including Mario Cuomo ${ }^{38}$ and Barack Obama. $^{39}$

Quite unsurprisingly, Rawls's ideal of public reason has brought sustained criticism from some quarters as being too discriminatory against religious beliefs. ${ }^{40}$ Many voices have joined the chorus of objections. Stephen Carter has protested that the Rawlsian approach "trivializes" religious belief in law and politics. ${ }^{41}$ Kent Greenawalt observed that citizens whose worldviews are primarily secular suffer less of a burden from the dictates of public reason than similarly situated religious believers." ${ }^{42}$ E.A. Goerner stated that "Rawls's new theory imposes second-class citizenship on most religious believers." ${ }^{43}$

(1993)). Note that here Griffin is citing the paper edition of POLITICAL LIBERALISM, which apparently included a revised or new introduction of the 1993 hardback edition I have cited earlier. Id. at 299 n.3.

36. Id. at 305 (citing RAWLS, supra note 1, at 126, 133-72).

37. Id. at 310-11 (emphasis added) (citing RAWLS, supra note 1, at 224-26).

38. Mario M. Cuomo, Religious Belief and Public Morality: A Catholic Governor's Perspective, 1 Notre DAME J.L. ETHICS \& PUB. PoL'Y 13, 17-18 (1984).

39. Barack Obama, THE AUdAcity Of Hope: THOUghtS ON REClaIMING THE AMERICAN DREAM 219 (2006)

40. Griffin, supra note 35, at 297.

41. Stephen L. Carter, The Culture of Disbelief: How American Law and Politics Trivialize Religious Devotion (1993).

42. Kent Greenawalt, On Public Reason, 69 CHI.-KeNT L. ReV. 669, 688 (1994).

43. E.A. Goemer, Rawls's Apolitical Political Turn, 55 Rev. Pol. 713, 715 (1993) (reviewing JOHN RAwLS, POLITICAL LIBERALISM (1993)). 
There is also the charge that public reason requires religious believers to "bracket" their cherished beliefs from the rest of their selves, undermining their psychological well-being and integrity. ${ }^{44}$ Michael Perry has gone so far as to suggest that such bracketing "annihilates" the believer, by requiring him to deny his true self. ${ }^{45}$ Michael McConnell more recently has agreed that "it is not reasonable to ask citizens who hold such beliefs to adhere to the principle of public reason." 46

Thus, the line has been drawn fairly clearly in the sand for some time now. On one side is the ideal of Rawlsian public reason and on the other side is the insistence on utilizing overtly Christian arguments regardless of other citizens' adherence. Both sides appear to agree on the underlying definition and premise of what a "religious" or "Christian" argument is, but simply differ on the propriety of using them. Next, I will turn to a discussion of how incorrect this shared premise is, and its implications for Christian principles in political argumentation and public reason.

\section{The Evangelical Christian Gospel: A WORLD APART}

Like Rawls and his adherents, I believe that the Christian political advocates, on both the Right and the Left, are making a mistake in their use of overt Christian argumentation in the public, political sphere. I find the political and democratic reasons given for the ideal of public reason compelling, including primarily respect for non-believing citizens. However, I have decided to add my voice to this debate to note a theological reason for the disagreement. I believe that it is a theological point that virtually all within the wider evangelical, Protestant community will unequivocally share. It is no mere ancillary point of theology, but rather one that is at the absolute center of our Christian faith. I have decided to add my voice to this debate, neither as an expert in liberal political philosophy, nor as a law and religion expert, nor as a theologian, but rather as an evangelical Christian who shares the same religious tradition as the advocates described in Part II.

Before proceeding with this Part, I wish to address two threshold issues. One is to clarify what I mean by "Evangelical" or "Protestant"

44. Griffin, supra note 35 , at 315 (citations omitted).

45. Michael J. Perry, Morality, Politics \& Law 72-73 (1988) ("To bracket [her moral and religious beliefs] would be to bracket, indeed, annihilate herself. And doing that would preclude her-the particular person she is-from engaging in moral discourse with other members of society.").

46. Michael W. McConnell, Secular Reason and the Misguided Attempt to Exclude Religious Argument from Democratic Deliberation, 1 J.L. PHIL. \& CULTURE 159, 173 (2007). 
Christian, and why I limit myself to this line of the Christian faith. David Smolin has defined "Evangelical Protestantism" as follows:

(1) Adherence to classic Christian orthodoxy, and hence to monotheistic Trinitarian theology, as reflected in ancient creedal statements such as the Apostle's and Nicene Creed.

(2) Acceptance of the Protestant Old Testament and New Testament canon as inspired scripture and the preeminent source of religious authority, with such scripture regarded as reliable and true (i.e. infallible/inerrant).

(3) An emphasis on a personal relationship between each individual believer and God, expressed as a relationship of trust and faith in Christ, which involves the individual turning away from sin and toward God (personal repentance).

(4) An emphasis on "evangelism," based on a biblical mandate to spread the Christian faith to persons of every national, ethnic, and cultural group. Thus, evangelicals believe that the Christian faith represents universal truth and the way of salvation applicable in every culture. ${ }^{47}$

Though it is difficult to claim perfect accuracy, this definition would seem to encompass the following: Baptists (including Southern Baptists), Fundamentalists, Pentecostals, Charismatics, many "nondenominational" Christian churches, and many (if not all) of the members of the mainline Protestant denominations including Methodists, Lutherans, Episcopalians, and Presbyterians. ${ }^{48}$ I certainly cannot possibly claim to speak with authority on behalf of these groups, as their beliefs and attitudes splinter on many subjects in many different areas. $^{49}$ But, as one who was raised in the Southern Baptist denomination, professed faith in Christ as a child, and has attended and served the church as a lay member in the South for his entire life, I believe I have a reasonable grasp of the evangelical Christian mindset.

So with the definition of evangelicalism out of the way, a follow-up point: Why limit the discussion to evangelical Christianity? One easy (and truthful) answer is that is what I am, and so that is what I understand. Another answer is that many, if not most, of the Christian political advocates described in Part II come from the evangelical Christian community-they are certainly the group that receives much of the attention (witness the public reaction to the name Jerry Falwell or Pat Robertson). Another answer is that the dominant group omitted by

47. David M. Smolin, Religion, Education, and the Theoretically Liberal State: Contrasting Evangelical and Secularist Perspectives, 44 J. CATH. L. STUD. 99, 99-100 (2005).

48. Id. at $100-01$.

49. Id. at $101-02$. 
this definition-the Catholic Church-has significant differences in theology even with respect to the points I am making in this Article, not to mention a formidable (and, to the newcomer, intimidating) body of centuries of teaching on social justice (from Augustine and Aquinas, to John Courtney Murray, and beyond). Therefore, although obviously the Catholic Church is an immensely respected community of faith, morality, and social justice, and has much to say on issues of politics and law, I am leaving uniquely Catholic thought aside for another day. The reason is simply that my message is to my fellow evangelical Christians and pertains particularly to a specifically evangelical theology.

The second threshold issue is: why should non-Christians care about this explicitly Christian theological discussion? My thesis is that my fellow evangelical Christians are making a missional and theological mistake, based on scriptural understandings from within our own tradition. So why does anyone else care? Or, as William Brewbaker has characterized the possible reaction from non-Christians: "Who cares? Why bother?" ${ }^{, 51}$ Perhaps the main response is that I think there is some value in simply airing this "in-house" debate in public. The Christian argumentation described in Part II has already been aired in the public square for public consumption, and presented as though it is "the" Christian position on the various issues. ${ }^{52}$ Therefore, any necessary correction ought also to occur in the public square, so as to correct any misimpressions of the faith. This point is actually raised by many in the Rawlsian debate on public reason. So, for instance, Rawls essentially left it up to each religious tradition to reconcile its tenets with the ideals of public reason. ${ }^{53}$ In fact, Rawls stated that in the event of an intrareligion conflict as to public reason, a value would be served by the opposing groups presenting "in the public forum how their comprehensive doctrines do indeed affirm those values." 54 Such affirmance in the public square by a religious perspective, Rawls noted, "surely strengthens mutual trust and public confidence; it can be a vital part of the sociological basis encouraging citizens to honor the ideal of public reason." Another reason non-Christians should care was raised

50. I hasten to add, of course, that the Catholic faith and the evangelical Christian faith have an immense degree of commonality as to many, if not even most, of the essentials of the Christian faith.

51. William Brewbaker, Who Cares? Why Bother?: What Jeff Powell and Mark Tushnet Have to Say to Each Other, 55 OKLA. L. REV. 533, 533 (2002) (reviewing H. JEFFERSON POWEll, THE MORAL TRAdITION OF AMERICAN CONSTITUTION: A TheOlogical INTERPRETATION (1993)).

52. See supra Part II.

53. See Griffin, supra note 35 , at 322.

54. RAWLS, supra note 1 , at 249.

55. Id. 
by Kent Greenawalt: "it informs them of the implications of one important religious and cultural perspective in our society; by introducing a perspective that varies from their own, it may enrich their sense of the significance of their own perspective and of alternative possibilities. 56

Finally, there is a sense in which it is more legitimate, and perhaps more amenable, for a member of the same Christian community to suggest opposing viewpoints for political engagement. When the "other" group - such as secular political philosophers-tells Christians they should not engage the public square with explicit Christian political argumentation, there is a sense of drawing lines in the sand of cultural battle. But, if there is an in-house debate among members of the same Christian community, hopefully there is a chance of greater possibilities of constructive change. Thus, as David Smolin has recently observed: "The real limitations on religious persons acting politically must come from within their own religious traditions, or from the practical necessities of operating within a religiously pluralistic society with certain traditions on such matters." within evangelical Christianity that I now turn.

\section{A. The Explicit Christian Gospel: Faith Alone}

Politics and law aside, there is a danger of misunderstanding and false teaching even within the church itself. Theologian D.A. Carson has stated "that a church is never more than three generations from losing the gospel: one generation to believe it and proclaim it, a second generation to assume it, and a third generation to lose it." ${ }^{958}$ Ironically, John Rawls himself, in his recently discovered undergraduate thesis which discussed some of his theological views at the time, remarked: "Although Christianity is said by all to be a very simple religion, it is surprising how few people understand it." $" 59$ One way that many evangelical leaders in the church today believe that the historical Christian gospel message is being lost within the church is by subtly teaching instead what has been called "Christian Moralistic Therapeutic Deism." "T0 "The idea behind moral, therapeutic deism is that we are able

56. Kent Greenawalt, Religious Convictions and Political Choice 217 (1988).

57. Smolin, supra note 47 , at 106.

58. "How Many Generations Does it Take for a Church to Die?," (July 25, 2011), http://in-the-meantime.com/201 1/07/25/how-many-generations-does-it-take-for-a-church-to-die/ (emphasis added) (last visited Dec. 23, 2012).

59. Peter Berkowitz, God and John Rawls, 155 Pol'Y Rev. (May 29, 2009) (quoting JOHN RAWLS, A BRIEF INQUIRY INTO THE MEANING OF SIN AND FAITH (Thomas Nagel ed., 2009)).

60. MATt ChandLer \& JARED Wilson, THE EXPLICIT GOSPEL 15 (2012) (citing Christian SMith with Melinda LundQuist Denton, Soul SEarching: The Religious and SPIRITUAL Lives Of AMERICAN TEENAGERS 118 (2009)). 
to earn favor with God and justify ourselves before God by virtue of our behavior." 61 This moralistic deism, although a somewhat "Christian"sounding mode of thinking, is about behavior (being good and avoiding bad) and tends in practice to be more about a kind of self-actualization than about an explicit theology of right standing before God. ${ }^{62}$ This shift, where the church has deemphasized (perhaps assumed) the historical gospel and instead focused on behaviorism, has prompted a recent book by evangelical pastor Matt Chandler entitled the Explicit Gospel, setting forth the explicit, central gospel message as accepted by historical Christianity in the evangelical tradition. ${ }^{63} \mathrm{As}$ Chandler states, I want "to make sure that when we use the word gospel, we are talking about the same thing." ${ }^{64}$ In setting forth the evangelical Christian "gospel on the ground," forth in his recent book, but will also show throughout that it is consistent in the essential points of doctrine discussed with the range of major Protestant evangelical views in the United States. ${ }^{66}$

61. Id. (emphasis added).

62. Id.

63. Id. at $15-16$.

64. Id. at 19 .

65. Chandler divides his presentation of the historical Christian gospel into two parts: the gospel on the "ground," and the gospel in the "air." Id. In "The Gospel on the Ground," "we will trace the biblical narrative of God, Man, Christ, Response." Id. This refers to individual salvation for man. Id. By "The Gospel in the Air," Chandler is referring to the greater picture of the fall of creation, and God's redemptive plan for the reconciliation of the wider creation and the plan to "make all things new." Id. at 19-20. Although both are obviously of immense importance to the evangelical Christian faith, I will only focus on Chandler's account of "The Gospel on the Ground," as it relates to man's individual salvation and I believe is more directly related to the issues of behaviorism and the law that I wish to discuss.

66. At the end of each of the four Parts of the evangelical Christian gospel presentation set forth herein in this Part III.A-God, Man, Christ, and Response-I will reference doctrinal statements from the following denominations representing a large percentage of evangelical Christianity in the United States today (in no particular order): the Southern Baptist Convention, the Evangelical Lutheran Church in America, the United Methodist Church, the Presbyterian Church (U.S.A.), the General Council of the Assemblies of God, Calvary Chapel, and the Episcopal Church in the United States. The doctrinal statement I will use for the Southern Baptist Convention is "The Baptist Faith and Message," www.americanrhetoric.com/speeches/ patrickbuchanan1992 $\mathrm{mc}$. htm [hereinafter Baptist Faith and Message]. The doctrinal statement I will use for the Evangelical Lutheran Church in America (ELCA) is the "Unaltered Augsburg Confession," because the ELCA adopts it as authoritative in the "ELCA Confession of Faith," http://www.elca.org/What-We-Believe/Statements-of-Belief/ELCA-Confession-of-Faith.aspx (last visited on Jan. 2, 2013). The doctrinal statement I will use for the United Methodist Church is The Articles of Religion of the Methodist Church, http://www.umc.org/site/c.lwL4KnN1LtH/ b.4846073/k.6B5F/Our_Doctrinal_Standards.htm (last visited Jan. 2, 2013). The doctrinal statement I will use for the Presbyterian Church (U.S.A.) is the Westminster Confession of Faith, as contained and modified in the Book of Confessions as published by the Presbyterian Mission Agency. See Presbyterian Mission Agency, "Statement on Theology," http://www. presbyterianmission.org/ministries/101/theology/ (last visited Jan. 2, 2013) ("Presbyterians confess their beliefs through statements that have been adopted over the years and are contained in The Book of Confessions."); http://www.pcusa.org/media/uploads/oga/pdf/boc.pdf (last 


\section{God}

The gospel begins, as it must, with God. "The work of God in the cross of Christ strikes us as awe-inspiring only after we have first been awed by the glory of God." ${ }^{\text {"67 }}$ In the book of Romans Paul writes of the glory of God:

Oh the depth of the riches and wisdom and knowledge of God! How searchable are His judgments and how inscrutable His ways! For who has known the mind of the Lord, or who has been His counselor? Or who has given a gift to $\mathrm{Him}$ that $\mathrm{He}$ might be repaid? For from Him and though Him and to Him are all things. To Him be glory forever. Amen. ${ }^{68}$

Deuteronomy 10:14 provides that "to the Lord your God belong heaven and the heaven of heavens, the earth with all that is in it." God's creativity is vast and expansive, and far beyond us. ${ }^{70} \mathrm{He}$ simply knows everything. ${ }^{71} \mathrm{He}$ "is incomprehensibly immense, exceedingly expansive, and eternally powerful."72 In response to Job's questioning of His ways, God responded: "Who is this that darkens counsel by words without knowledge? . . Where were you when I laid the foundation of the earth? Tell me, if you have understanding." ${ }^{, 73}$ What is more, God is perfectly self-sufficient. As a passage from Romans states, "who has given a gift to God that he might be repaid?"74 This means that you cannot put God into your debt, and God owes nothing to any man. ${ }^{75}$ Because everything belongs to God, we have nothing with which we can negotiate or bargain with Him. ${ }^{76}$

God also has an ultimate glorious self-regard. $\mathrm{He}$ is the most excellent thing that exists, and so it only makes sense that He values

visited Jan. 2, 2013). The doctrinal statement I will use for the General Council of the Assemblies of God is their Statement of Fundamental Truths, http://agchurches.org/Sitefiles/ Default/RSS/AG.org\%20TOP/Beliefs/SFT_2011.pdf. The doctrinal statement I will use for The Episcopal Church in the United States is THE BOOK OF COMMON PRAYER, http://www.episcopal church.org/sites/default/files/downloads/book_of_common_prayer.pdf.

67. ChANDLER \& WILSON, supra note 60 , at 23.

68. Id at 23-24 (quoting Romans 11:33-36 (ESV)).

69. Id. at 26 (citing Deuteronomy 10:14 (ESV)).

70. Id. at 27.

71. Id. at 29-30 (describing God's infinite knowledge, including: every book that will ever be written, the temperature of the stars, the oceans' depths, every event of history and the future, the velocity of a butterfly's wings).

72. Id. at 31 .

73. Id. at 28 (quoting $J o b$ 38:2-4 (ESV)).

74. Id. at 30 (quoting Romans 11:35 (ESV)).

75. Id.

76. Id. at $30-31$. 
Himself above all things. "From beginning to end, the Scriptures reveal that the foremost desire of God's heart is not our salvation but rather the glory of His own name. God's glory is what drives the universe; it is why everything exists."78 Although the scriptures contain many ethical teachings, that is not the primary point and neither is the salvation of man-rather, the meta-narrative of the scriptures is the glorification of God in his infinite perfection. ${ }^{79}$ It is unavoidably and pervasively the overall theme of scripture. ${ }^{80}$ The scriptures provide that "the earth will be filled with the knowledge of the glory of the Lord as the waters cover the sea." 81 This is why the champions of the Reformation proclaimed "soli Deo Gloria (glory to God alone.)"82 Thus, the story of the Bible is not man, but rather "God and God alone, God's name and namesake alone. The point of everything is God's glory alone so that to God alone will be the glory." 83 Or as theologian and pastor John Piper put it: "The further up you go in the revealed thoughts of God, the clearer you see that God's aim in creating the world was to display the value of his own glory." 84 This is why the Westminster Confession of Faith begins by biblically answering the question of the meaning of existence: "The chief end of man is to glorify God and to enjoy Him forever." saying "worship":

77. Id. at $36-41$.

78. Id. at 33-34 (emphasis added).

79. Id. at $38-39$.

80. Id. at $34-35$.

According to Scripture: [f] or the sake of his name, God did not destroy Israel in the desert (Ezek. 20:5-9). God saves men for His name's sake (Ps. 106:8). Pharaoh's heart was hardened for the glory of God (Ex. 14:4, 18). The beginning of the Israelite monarchy was about the glory of God (1 Sam. 12:1919-23). Solomon dedicated the temple for the glory of God (1 Kings 8). Israel became great and powerful among the nations because God was 'making himself a name' (2 Sam. 7:23). God did not destroy Israel when it deserved to be destroyed, because he did not want his name blasphemed among the nations (Isa. 48:9-11). God decided to destroy the Israelites because they would not lay it in their heart to give glory to his name (Mal. 2:2). Jesus's life and ministry was about the glory of God (John 7:18, 17:4). The cross of Jesus is about the glory of God (John 12:27-28). You and I are saved to the praise of his glorious grace (Eph. 1:3-6). The Christian life is about the reflection of the glory of God off of our lives into the universe (Matt. 5:16;1 Cor. 10:31; 1 Pet. 4:11). The second coming is about the consummation of the glory of God ( 2 Thess. 1:910). The consummation of all things is that God might be praised (Rev. 21:23).

81. Id. at 35 (quoting Habakkuk 2:14 (ESV)).

82. Id.

83. Id.

84. Id. (quoting JOHN PIPER, God's Passion for HIS GloRY: LIVING THE VISION OF JONATHAN EDWARDS 32 (1998)).

85. Id. at 34 (emphasis added). 
Worship is the attributing of ultimate worth to something. When this ultimate worth is attributed to anyone or anything other than the one, true triune God of the universe, it is idolatry. The root of Christian worship, then, is acknowledging, submitting to, and enjoying the supremacy of God's glory. In all things. ${ }^{86}$

The scriptures teach that we should glorify God and worship Him in all things. "The heavens declare the glory of God." 87 Therefore, Paul admonished the church in Corinth that "whether you eat or drink, or whatever you do, do it all for the glory of God." ${ }^{\prime 88}$ There is substantial agreement across American Christian evangelicalism in regard to the supreme significance of God and His ultimate worthiness for worship. ${ }^{89}$ Unfortunately, the scriptures reveal that the current natural state of man is not one of worship and attribution of glory to God. ${ }^{90}$ It is to that state that the gospel narrative next takes us.

\section{Man}

Although evangelical Christians believe that man was designed for the worship and glorification of God, the scriptures reveal that we do not naturally do so. ${ }^{91}$ As C.S. Lewis once colorfully stated:

God made us: invented us as a man invents an engine. A car is made to run on petrol, and it would not run properly on anything else. Now God designed the human machine to run on Himself. He Himself is the fuel our spirits were designed to burn, or the food our spirits were designed to feed on. There is no other. That is why it is just no good asking God to make us happy in our own way without bothering about religion. God cannot give us a happiness and peace apart from Himself, because it is not there.

86. Id. at 36 .

87. Psalms 19:1 (ESV).

88. 1 Corinthians 10:31 (ESV).

89. See Part II, God, in Baptist Faith and Message, http://sbc.net/bfm/bfm2000.asp; Art. $\mathrm{I}$, of God, in Lutheran Augsburg Confession, http://bookofconcord.org/augsburg confession.php\#article1.2; Of Faith in the Holy Trinity, THE ARTICLES OF THE RELIGION OF THE METHODIST CHURCH, http://master.umc.org/interior.asp?ptid=1\&mid=1817; Of God, and of the Holy Trinity, THE BOOK OF CONFESSIONS 124(b), available at http://www.pcusa.org/ media/uploads/oga/pdf/boc.pdf; The One True God, STATEMENT OF FUNDAMENTAL TRUTHS 1, available at http://agchurches.org/Sitefiles/Default/RSS/AG.org\%20TOP/Beliefs/SFT_2011. pdf; Calvary ChaPel, http://www.calvarychapel.com/about/; THE BOOK OF COMMON PRAYER 846, http://www.episcopalchurch.org/sites/default/files/downloads/book_of_common_prayer. pdf.

90. CHANDLER \& WILSON, supra note 60 , at 37 .

91. Id. at 39. 
There is no such thing. ${ }^{92}$

So we were designed by God for worshipping and treasuring Him above all things.

But what happens when instead of using that gift of worship from God for God, we terminate our worship on the stuff God made? What happens when we attempt to hijack God's story about himself and rewrite it with ourselves at the center? This is insurrection. It is infernal mutiny. ${ }^{93}$

Evangelicals believe that this is the state-fallen sinfulness-of all humanity in its natural state. This has been the case ever since the fall of man, since the first rebellion against God in the garden-the initial sin of Adam and Eve created a rupture in the creative order and in man's relationship with God. ${ }^{94}$ The scriptures reveal that the universe itself shudders in horror at man's rebellion and idolatry in failing to give God the worship and glory to which He is entitled. ${ }^{95}$ This is because we are guilty before God-everyone in the human race now is born into this rebellious state. As David said in the Psalms, "Behold, I was brought forth in iniquity, and in sin did my mother conceive me." 96

Therefore in the book of Romans Paul states to "[n]ote then the kindness and severity of God." grace, healing and forgiveness-is absolutely pervasive, correct, and worthy of worship. However, God's severity is not nearly as popular (nor politically correct) of a concept. ${ }^{98}$ Although it is unpopular, and often ridiculed and minimized as a fundamentalist concept out of touch with enlightened, modernist thinking, there is no escaping the evangelical Christian adher

ence to the concept of God's severity in response to man's rebellion against attributing ultimate worth to God. A couple of key scriptures noting God's severity in relation to man's rebellion (sin) are Romans 6:23: "For the wages of $\sin$ is death," and Romans 3:23: "All have sinned and fall short of the glory of God." $" 99$ Thus, the scriptures reveal that man is deserving of God's perfectly just wrath for our infinite treason against the God of the universe. Twelve times in the four gospel

92. C.S. LEWIS, MERE ChRISTIANITY 50 (Harper Collins ed. 2001).

93. CHANDLER \& WILSON, supra note 60 , at 39 (emphasis added).

94. See id. at 129-57 (describing the fall generally).

95. See id. at 39-40. See also Jeremiah 2:11-12 (ESV) ("Be appalled, O heavens, at this; be shocked, be utterly desolate.").

96. Id. at 99 (quoting Psalms 51:5 (ESV)).

97. Id. at 40 (quoting Romans 11:22 (ESV)).

98. Id. at $40-41$.

99. Id. at 43 (quoting Romans 3:23 (ESV)). 
accounts, Jesus uses the word Gehenna as a description of God's forthcoming wrath-a Greek word translated as "hell." "100 Gehenna, or hell, is described in the scriptures as the absence of God, or anything good or joyous - it is described as a place of gnashing of teeth and eternal torment. ${ }^{101}$ Many, perhaps most, get no further than this in hearing the Gospel narrative - God should be love, they say, and people are mostly good. "The punishment does not fit the crime."102 "But to discount the enormity of God's severity, as if we aren't really that bad and really deserve mostly kindness, is to discount the enormity of God's holiness." "103 Or, as John Piper has said, hell "is a just and righteous recompense to all who sin. And for that to be true, how infinitely valuable and worthy must be the glory of God that sin belittles and scorns! In other words the horror of hell is an echo of the infinite worth of God's glory."104 Thus, "to seek our benefit outside God's glory demands the response of eternal fire." 105

Evangelical Christians believe that our deserving of God's wrath for rebellion against Him is true information, and thus very good and monumentally important to know. ${ }^{106}$ But, even realization of hell cannot create worship - "misunderstanding this reality is historically how the doctrine of hell has been abused and misused by so many men in the name of God." 107 People cannot be scared into salvation. They can perhaps be scared into acting morally (and such activity is often mislabeled "Christian"), but cannot be scared into loving God. ${ }^{108}$ So what is the point of discussing it in the context of the gospel narrative?

Because you can't understand the cross of Christ without understanding the weight of the glory of God and the offense of belittling His name and what the due punishment is for that offense. What Christ did on the cross will not be revelatory in transforming love until we see that the cross is revelatory also in the depth of the offense of $\sin .^{109}$

100. Id. at 42 . (ESV)).

101. Id. at 43-44 (quoting Matthew 8:12 (ESV); Mark 9:48 (ESV); Revelation 14:11

102. Id. at 45 .

103. Id. at 44 .

104. John Piper, "The Echo and the Insufficiency of Hell, Part 2," sermon preached at Bethlehem Baptist Church, Minneapolis (June 21, 1992), available at http://www.desiringgod. org/resource-library/sermons/the-echo-and-insufficiency-of-hell-part-2) (last visited on Dec. 24, 2012).

105. ChANDLER \& WiLSON, supra note 60 , at 47.

106. $I d$. at 48 .

107. Id. at 49 .

108. Id.

109. Id. at $49-50$. 
Or, as Thomas Watson put it: "Till sin be bitter, Christ will not be sweet." 110 And, as Chandler puts it near the conclusion of his chapter on the state of Man: "We have to feel the weight of God's severity, because without feeling the weight of his severity, we won't know the weight of his kindness, and we won't be able to worship him and him alone." 111 And on the sinful state of man and his need for redemption, there is substantial agreement across American Christian evangelicalism. ${ }^{112}$ It is at this point of the gospel account and man's state of utter hopelessness that the cross of Christ intervenes.

\section{Christ}

Thus far the scriptural account has been that God is infinitely glorious and worthy of worship, but that man is fallen, rebellious, and falls well short of the glory of God, choosing instead to elevate man and things over God. ${ }^{113}$ Because God is infinitely deserving of our worship and $\mathrm{He}$ is perfectly just, our failure to worship and glorify Him is correspondingly deserving of infinite wrath. ${ }^{114}$

The problem is that ... there is a chasm between God and us, and the problem compounding that problem is that not only does our sinfulness cause this chasm, but our sinfulness prevents us from being able to bridge the chasm ourselves. . . . We have dug ourselves into a grave too deep to climb out. We need radical intervention. $^{115}$

God's salvation offered to man is done through the miraculous person of Jesus Christ:

The place the gospel holds out for us is where God's kindness and his severity meet. This place is called the cross, and it is

110. Id. at 50 (quoting Thomas Watson, The Doctrine of RePENTANCE 63 (1988)).

111. ChANDLER \& WiLson, supra note 60 , at 51 .

112. See Man, in Baptist Faith and Message, http://sbc.net/bfm/bfm2000.asp; Of Original Sin, The AugSBURG CONFESSION, http://bookofconcord.org/ augsburgconfession.php\#article2; Of Original or Birth Sin, ARTICLES OF METHODIST CHURCH, http://www.umc.org/site/apps/nlnet/ content.aspx? $\mathrm{c}=\mathrm{lwL} 4 \mathrm{KnN} 1 \mathrm{Lt} \mathrm{H} \& \mathrm{~b}=5068507 \& \mathrm{ct}=6466481$ \&notoc $=1$; The Constitution of the Presbyterian Church, THE BOOK OF CONFESSIONS 128, http://www.pcusa.org/media/uploads/ oga/pdf/boc.pdf; \& 4, The Fall of Man, STATEMENT OF FUnDAMENTAL TRUTHS, at 3, http://agchurches.org/Sitefiles/Default/ RSS/AG.org\%20TOP/Beliefs/SFT_2011.pdf; CALVARY CHAPEL, http://www.calvarychapel.com/home/about/; Sin and Redemption, Episcopal Catechism, THE BOOK OF COMMON PRAYER, 848-49, available at http://www.episcopalchurch. org/sites/default/files/downloads/book_of_common_prayer.pdf.

113. CHANDLER \& WILSON, supra note 60 , at 53 .

114. Id.

115. Id. 
where grace and wrath intersect. It is at this place of shame and victory that God, in the form of the man Jesus of Nazareth, the long-expected Messiah, offered in his death the blood atonement necessary to satisfy God's justice and secure our salvation. ${ }^{116}$

The cross of Christ is God's response to man's belittlement of His name. ${ }^{117}$ The scriptures teach that Jesus was God Himself, supernaturally incarnated into the flesh of man, offering Himself as the only possible perfect sacrifice to satisfy the wrath of God for the sinful nature of mankind. ${ }^{118}$ Probably the most universally cited gospel verse is John 3:16: "For God so loved the world, that he gave his only Son, that whoever believes in him should not perish but have eternal life."119 Romans 5:8 provides that "Christ demonstrated his own love for us, in that while we were yet sinners, Christ died for us." ${ }^{\text {120 }}$ Christ's sacrifice on the cross was an amazing display of love-Christ said: "No one takes My life from Me. I lay it down."

The concept of the removal of sin by blood sacrifice had been established by God thousands of years earlier in the system of Mosaic law with the Israelite people. ${ }^{122}$ "The sacrificial system was instituted under the established truth that to dwell in God's holy presence requires perfection."123 The author of the book of Hebrews later ties the Old Testament system of sacrifice to Christ's sacrifice: "[w]ithout the shedding of blood there is no forgiveness of sins." 24 The former was a shadow and precursor of the latter. The animals sacrificed under the Old Testament system represented the need for satisfaction of God's wrath for the Israelites' sin, an act that was ultimately and completely finalized in Christ's perfect sacrifice. ${ }^{125}$ Hence the "Lamb of God" title given to Christ by John the Baptist, connecting the old system of Jewish sacrifices with the new covenant instituted through Christ's sacrifice: "Behold the Lamb of God who takes away the sins of the world."126 It was part of God's predetermined plan for the ages, and the "cross now stands as the central tenet of all we believe about salvation." 127 Not only did Christ die, but he resurrected three days later in victory over deaththus, Paul recounts the simple, unadulterated gospel in his first letter to

116. Id. at 54 .

117. Id. at 55 .

118. Id. at 55-58.

119. John 3:16 (ESV).

120. Romans 5:8 (ESV).

121. ChANDLER \& WILSON, supra note 60 , at 67 (citing John 10:18 (ESV)).

122. Id. at 60 .

123. $I d$.

124. Id. at 54 (citing Hebrews 9:22 (ESV)).

125. Id. at 61 .

126. Id. at 62 .

127. $I d$. at 58 . 
the church at Corinth:

Now I would remind you, brothers, of the gospel I preached to you, which you received, in which you stand, and by which you are being saved, if you hold fast to the word I preached to youunless you believed in vain. For I delivered to you as of first importance what I also received: that Christ died for our sins in accordance with the Scriptures, that he was buried, that he was raised on the third day in accordance with the Scriptures. ${ }^{128}$

On the historical sacrifice and resurrection of Christ for man's sin there is of course consistent agreement across American evangelicalism. ${ }^{129}$ The only thing then that remains to discuss in this account of the evangelical Christian gospel is man's response to Christ's sacrifice on man's behalf.

\section{Response}

Evangelical Christians maintain that "[t]he gospel is news, not advice or instruction, but it nevertheless demands a response." 130 What response? Faith. As cited above, John 3:16 provides: "For God so loved the world, that he gave his only Son, that whoever believes in him should not perish but have eternal life."131 Belief-namely, faith is the simple response God desires. In another scripture, the apostle Paul's letter to the Romans provides: "If you will confess with your mouth that Jesus is Lord and believe in your heart that God raised him from the dead, you will be saved." 132 God desires man's faith in His provision of salvation on our behalf. "Believing the news that God is holy, that you are a sinner, and that Christ has reconciled you to God by his life, death, and resurrection is what justifies [i.e., saves] you. This is our

128. I Corinthians 15:1-4 (ESV) (emphasis added).

129. See God the Son, BAPTIST FAITH AND MESSAGE, at http://sbc.net $/ \mathrm{bfm} / \mathrm{bfm} 2000$.asp; Of the Son of God, THE AUGSBURG CONFESSION, http://bookofconcord.org/augsburgconfession. php\#article3; Articles II and III, The ARTICLES OF RELIGION OF THE METHODIST CHURCH I-IV, http://www.umc.org/site/apps/nlnet/content.aspx?c=lwL4KnN1LtH\&b=5068507\&ct $=6466475$ \&notoc $=1$; $\S \S 6.043-6.050$, Of Christ the Mediator, Presbyterian Westminster Confession, at 129-31 of pdf, available at http://www.pcusa.org/media/uploads/oga/pdf/boc.pdf; $\S 3$, The Deity of the Lord Jesus Christ, STATEMENT OF FundamENTAL TRuTHS, at 3, http://agchurches.org/Sitefiles/Default/RSS/AG. org\%20TOP/Beliefs/SFT_2011.pdf; CALVARY CHAPEL, at http://www.calvarychapel.com/ about/; God the Son, Episcopal Catechism, THE BOOK OF COMMON PRAYER, at 849-50, available at http://www.episcopalchurch.org/sites/ default/files/downloads/book_of_common_prayer.pdf.

130. CHANDLER \& WILSON, supra note 60 , at 84.

131. John 3:16 (ESV) (emphasis added).

132. CHANDLER \& WILSON, supra note 60, at 85 (emphasis added) (citing Romans 10:9 (ESV)). 
foundation, our root." ${ }^{\prime 33}$ As Chandler further states:

The gospel is such power that it necessitates reaction. Jesus Christ has worked such an outrageous wonder that he demands response, whether hatred or passion. Anyone ambivalent about what Christ has actually done just isn't clear on the facts. To present the gospel, then, is to place a hearer in an untenable position. The heart of the hearer of the gospel must move, either toward Christ or away from him. Pastor Chan Kilgore puts it this way: "True gospel preaching always changes the heart. It either awakens it or hardens it." 134

Thus faith, and faith alone, is the only response to Christ's sacrifice on our behalf which results in a reconciled, restored relationship with God. Man's only response is a simple, even childlike, ${ }^{135}$ belief in God's provision of Christ's sacrifice and resurrection as atonement for our sin and the means of a reconciled, restored relationship with God. Conversely, the natural response of man to this is, quite simply, that it is absolute nonsense-complete, utter foolishness: "For the word of the cross is folly to those who are perishing, but to us who are being saved it is the power of God." 136 Another scripture from the book of Proverbs perhaps echoes this same mystery: "There is a way that seems right to a man, but its end is the way to death." ${ }^{137}$ Nevertheless, faith and faith alone is the only response called for by God which will result in justification (i.e., salvation), according to the historic, evangelical gospel, and this continues as a shared tenet across American evangelicalism. ${ }^{138}$ Of course, Christian theology is thick with additional

133. Id. at 83 .

134. Id. at 63 (quoting Chan Kilgore, "Mission" Sermon at the Resurgence Conference (Feb. 2, 2011), available at http://theresurgence.com/2011/03/31/chan-gilgore-mission).

135. See Matthew 18:2-4 (ESV):

And calling to him a child, he [Jesus] put him in the midst of them and said, "Truly, I say to you, unless you turn and become like children, you will never enter the kingdom of heaven. Whoever humbles himself like this child is the greatest in the kingdom of heaven.

136. I Corinthians 1:18 (ESV) (emphasis added).

137. Proverbs 14:12 (ESV).

138. See Salvation, BAPTIST FAITH AND MESSAGE, at http://sbc.net/bfm/bfm2000.asp; of Justification, THE AUGSBURG CONFESSION, http://bookofconcord.org/augsburgconfession.php\# article4; Article IX, The ARTicles of Religion of the Methodist ChURCh, http://www.umc. org/site/apps/nlnet/content.aspx? $=1 w L 4 K n N 1 L t H \& b=5068507 \& \mathrm{ct}=6466483 \&$ notoc $=1 ; \quad$ Of Justification, Presbyterian Westminster Confession, THE BOOK OF CONFESSIONS, $\S \S 6.068$ 6.073, at 135-36, http://www.pcusa.org/media/uploads/oga/pdf/boc.pdf; The Salvation of Man, STATEMENT OF FUNDAMENTAL TRUTHS, $\S 5$, at 1 , available at http://agchurches.org/Sitefiles/ Default/RSS/AG.org\%20TOP/Beliefs/SFT_2011.pdf; CALvARY CHAPEL, at http://www.cal varychapel.com/about/; Episcopal Catechism, THE BOOK OF COMMON PRAYER, at 850-51, 
implications beyond the initial act of faith, but none matter until that initial threshold is crossed - the "explicit gospel, by virtue of its own gravity, [simply] invites belief." 139 As Jesus told his followers in the book of John: "This is the work of God, that you believe in him whom he has sent." $" 140$

\section{B. The Mistake of Works-Based Moralism}

As has been seen, the unadulterated Christian gospel is faith alone in the atoning sacrifice of Christ and resurrection. There is nothing we can do besides trust in God for this method of reconciliation. "[B] ut one of our biggest problems is mistaking the gospel for law."141 This mistake is one that is as old as God's dealing with man as recounted in the scriptures. As discussed earlier, the scriptures reveal that God, in a shadow designed to point toward Christ's eventual sacrifice, commanded the Israelites to perform animal sacrifices to make atonement for their sins. ${ }^{142}$ God appears to have meant for this to produce repentant hearts, but instead too often the performance of the rituals were perceived as the end result. A passage from the prophet Isaiah is indicative:

Hear the word of the Lord, you rulers of Sodom!

Give ear to the teaching of our God, you people of Gomorrah!

"What to me is the multitude of your sacrifices?"

says the Lord;

I have had enough of burnt offerings of rams

and the fat of well-fed beasts;

I do not delight in the blood of bulls, or of lambs, or of goats.

When you come to appear before me, who has required of you this trampling of my courts? ${ }^{143}$

As Chandler translates:

available at http://www.episcopalchurch.org/sites/default/files/downloads/book_of_common_ prayer.pdf.

139. CHANDLER \& WILSON, supra note 60 , at 63 .

140. John 6:29 (ESV) (emphasis added).

141. CHANDLER \& WILSON, supra note 60 , at 64 (emphasis added).

142. Id. at 67 ("Hebrews 10:1 tells us the law is just the shadow of the good things to come.").

143. Id. at 64 (quoting Isaiah 1:10-12 (ESV)). 
God is saying, "I don't need your bulls. I don't want your goats. You're missing the point. I'm trying to communicate to you how disgusting and how horrible and how costly your sin is before me. And instead of feeling the weight of that and actually repenting, you just keep doing what you're doing, all the while bringing me goats and bulls like that's what I really want."144

As Chandler further states, "[t]he same thing plays out even to this day. Christ's work demands the response of faith, but we want to make donations. It is astounding how many evangelicals are not doing Christianity at all; they're doing the Levitical priesthood."145

The faith versus works error was also made by some first century Christians and is actually the primary subject of the book of Galatians (Paul's letter to the churches in Galatia). ${ }^{146}$ The new Christians in Galatia, although they had recently professed faith in Christ, had fallen back into behavioral-based works of the Mosaic law as a supplemental way to continue to earn God's favor. Paul opened his letter by saying: "I am astonished that you are so quickly deserting him who called you in the grace of Christ and are turning to a different gospel - not that there is another one, but there are some who trouble you and want to distort the gospel of Christ." ${ }^{147}$ Later in the book he expressed the same sentiment: "O foolish Galatians! Who has bewitched you? ... Did you receive the Spirit by works of the law or by hearing with faith?"148 Paul corrected them in the accurate understanding of the Christian gospel by admonishing the Galatians:

[W]e know that a person is not justified [saved] by works of the law but through faith in Jesus Christ, so we also have believed in Christ Jesus, in order to be justified by faith in Christ and not by works of the law, because by works of the law no one will be justified. ${ }^{149}$

This issue of law (works) versus faith was also a central issue in the Reformation of the sixteenth century. ${ }^{150}$ That is, Luther initiated a break from the Roman Catholic Church over the very issue of whether faith alone was sufficient for salvation, or whether some form of works were also necessary:

144. Id. at 65 .

145. Id.

146. See Galatians 1:1-2 (ESV).

147. Id. 1:6-7 (emphasis added).

148. Id. $3: 1-3$.

149. Id. 2:16 (emphasis added).

150. Peter Cumper \& Tom Lewis, "Taking Religion Seriously?" Human Rights and Hijab in Europe-Some Problems of Adjudication, 24 J.L. \& RELIGION 599, 606 (2009). 
[Martin] Luther held that man was justified (saved) by faith alone: the words sola fide came to be the watchword and touchstone of the Reformation. Man could do nothing by his own works-whether works of edification like prayer, fasting, mortification, or works of charity-to compel justification. But if he believed, God of His grace would give him the gifts of the Holy Spirit-salvation and eternal life.

Thus, the relationship of the law and gospel was one of Luther's central concerns that eventually brought about the Reformation. At bottom, this aspect was concerned with man's tendency to misperceive that his own behavioral efforts were in part necessary in order to gain favor with God.

The same thing that was true of the Old Testament Israelites, the first century Christians in Galatia, and the Christians of the sixteenth century in Luther's day, is still unfortunately prevalent in the evangelical Christian community today. The response to Christ's sacrifice is simple faith and trust, but people in their supposed wisdom believe they can improve upon God's prescription, and offer up their good works as well. "Christ's work demands the response of faith, but we want to make donations. ... . [People are] trying to offer God good behavior so he'll like them." ${ }^{\text {"153 }}$ This system of favor with God because of good works that we do makes innate sense to our human sensibilities, and "[w]hen someone [instead] dares to insert the unadulterated gospel into this religious mess [i.e., salvation by faith alone], we get discombobulated." 154 Of course, it is true that the scripture is filled with codes of behavior and works, largely in the Mosaic law, but this was all part of the shadow pointing toward Christ who became the fulfillment of the law ${ }^{155}$ - it turns out that the law was given by God not to provide man a way to gain favor with God, but rather ultimately to convict men of their sin and inability to sufficiently please God by their works no matter how hard they try. ${ }^{156}$ By the law alone, no one would obtain salvation because "no one does good; no, not one."157 As the book of John puts it: "For the law was given through Moses; grace and truth

151. Id. (quoting G.R. ELTON, ReFORMATION EUROPE 1517-1559, at 16 (1963)).

152. Id.; see also Joshua Mitchell, Legal Teachings of the Protestant Reformation (book review), 52 EMORY L.J. 953, 954-55 (2003). On my omission of Catholic theology from this Article, see supra note 50 and accompanying text.

153. CHANDLER \& WiLSON, supra note 60 , at 75 (emphasis added).

154. Id.

155. Hebrews 10:1-7 (ESV); Romans 10:1-4 (ESV).

156. Romans 7:7-12 (ESV).

157. Id. 3:10-12 ("it is written: 'None is righteous, no, not one; no one understands; no one seeks for God. All have turned aside; together they have become worthless; no one does good, not even one."). 
came through Jesus Christ." 158

The mistake of law-based moralism gets two things, salvation through faith and righteous works, confused as to their ordering with respect to reconciliation with God. It is no doubt true in evangelical Christian theology that a person's profession of faith in Christ should not be the last event in a person's life of devotion to God. James in fact tells us that faith, unless accompanied by righteous works, is dead. ${ }^{159}$ Christians actually believe that when they place their faith in Christ, they are supernaturally empowered more and more to do such righteous works by being imbued with the righteousness of Christ Himself ${ }^{160}$ (albeit such righteousness still wars with the flesh-i.e., the person's natural sinful tendencies). ${ }^{161}$ Thus, it is no doubt true that a genuine, believing Christian should be spiritually spurred on to good works, such as helping their fellow man, or engaging in more moral behavior. However, this is a result, and not a cause, of favor with God, as theologian D.A. Carson has noted:

The kingdom of God advances by the power of the Sprit through the ministry of the Word. Not for a moment does that mitigate the importance of good deeds and understanding the social entailments of the gospel, but they are entailments [i.e., results] of the gospel. It is the gospel that is preached. ${ }^{162}$

Man's efforts to be righteous absent faith are therefore worthless to God; the prophet Isaiah states that they are basically nothing but "filthy rags" in God's sight. ${ }^{163}$ As Chandler states: "The religious, moralistic, churchgoing evangelical who has no real intention of seeking God and following him has not found some sweet spot between radical devotion and wanton sin; he's found devastation."164

Thus, rather than moralistic works, faith is the only hope. Indeed, the scriptures state that "without faith it is impossible to please God." "165 Whereas man tends naturally to think that he must act righteously in order to gain favor with God, in fact it is the reverse:

[T] he shadow of good works ought to proceed from the light of

158. John 1:17 (ESV).

159. James 2:14-26 (ESV).

160. 2 Corinthians 5:21 (ESV) ("For our sake he made him to be $\sin$ who knew no $\sin$, so that in him we might become the righteousness of God.").

161. Romans 7:13-25 (ESV).

162. Chandler \& Wilson, supra note 60, at 97 (citing D.A. Carson, Scandalous: The CROSS AND RESURRECTION OF JESUS $105-06$ (2010)).

163. Isaiah 64:6 (ESV).

164. Chandler \& Wilson, supra note 60 , at 81 (emphasis added).

165. Hebrews 11:6 (ESV). 
the good news. ... The gospel of the sacrifice of Christ on the cross, then, is not an invitation to moralism; it is an invitation to real transformation. Our works don't work. "For we hold that one is justified by faith apart from works of the law," Paul writes in Romans 3:28. The only acceptable response to the gospel is nothing less than a heart of faith. ${ }^{166}$

\section{Christian Political Argumentation = Works-Based Moralism}

By now, it should be clear that the essential complaint I have with the "Christian" political argumentation illustrated in Part II is that the expressed message to the public about the Christian gospel is wrong. When political advocates-from either the Religious Right or the Religious Left-champion some candidate, law or policy based explicitly on the fact that a vote for him (or her or it) is required by "Christian" principles or "values," this is an absolutely incorrect theological message from the evangelical Christian perspective. Law is about inherently coerced standards of behavior, backed and enforced by the violence of the State. ${ }^{167}$ Christianity is understood by the public (even by Rawls!) as making a salvationist claim - that is, a claim that adherence and subjection to its principles will result in favor with God and indeed, salvation of their souls. ${ }^{168}$ Cass Sunstein has astutely noted that laws carry unavoidably expressive meanings. ${ }^{169}$ When groups or citizens from either the Religious Right or the Religious Left tell the public that a vote for them is necessary for compliance with "Christian" values, the message is that the acts or works of their vote (and their compliance with any law once enacted on the books) will result in favor with God by virtue of the "Christian-ness" of such works. ${ }^{170}$ This is communicating a works-based moralism, and it is just as incompatible with the historic evangelical Christian gospel for current society as it was to the first-century Galatians and the sixteenth-century church in Martin Luther's day. Such works-based argumentation is completely at odds with the simple evangelical Christian message that " $[b]$ elieving the news that God is holy, that you are a sinner, and that Christ has reconciled you to God by his life, death and resurrection is what justifies [saves] you." $" 171$ It is completely at odds with the evangelical message, consistent from the time of Luther that salvation comes by

166. CHANDLER \& WILSON, supra note 60, at 78-79 (quoting Romans 3:28 (ESV)).

167. See Yankah, supra note 11, at 1244.

168. See, e.g., Rawls, supra note 1 , at $\mathrm{xxi}$, xxiii (describing Christianity as being a "religion of salvation"). (1996)

169. See Cass R. Sunstein, On the Expressive Function of Law, 144 U. PENN. L. REv. 2021

170. See supra Part II.

171. ChANDLER \& Wilson, supra note 60 , at 98 (emphasis added). 
faith alone. $^{172}$

In his book, Chandler observes the tendency of confusion that occurs when the simple gospel message of faith is mixed with other messages:

If we confuse the gospel with response to the gospel [i.e., good works resulting after a salvation experience], we will drift from what keeps the gospel on the ground, what makes it clear and personal, and the next thing you know, we will be doing a bunch of different things that actually obscure the gospel, not reveal it. $^{173}$

This is what I fear occurs when advocates from the Religious Right or Left make their explicit appeals to Christian values in order to persuade their fellow citizens. They are obscuring the true gospel message of salvation by faith alone. They are obscuring it with an injection of law and works-based morality being tinged with appeals to Christianity. Samuel Calhoun echoed a similar sentiment in 1992 in his discussion of the works of Kent Greenawalt and David Smolin and their appeals to allow Christian thought to be injected into democratic deliberation of law and policy:

Christianity teaches that each person has sinned and fallen short of the glory of God, despite the outward "righteousness" of one's conduct. ... The heart of the Christian message is that the only way to righteousness before God is through faith in Jesus Christ, who on the cross paid the penalty for sin. Emphasis upon human law as the road to righteousness perpetuates a cruel delusion, like the story of Scrooge at Christmastime. Both direct people's attention to their own conduct as the avenue to acceptability before God, when in truth acceptability lies only in trusting Jesus Christ as Savior. Conduct is important, not as the avenue to God, but as the response of a grateful heart to God's provision of the only way to Him-Jesus Christ. ${ }^{174}$

Thus, as Calhoun correctly observed, "[h]uman coercion can play no role in another's decision to become a Christian." Implying otherwise through Christian political argumentation that effectuates an inaccurate and imprecise conflation of secular law and the Christian faith

172. Cumper \& Lewis, supra note 150.

173. CHANDLER \& WiLSON, supra note 60 , at $98-99$ (emphasis added).

174. Samuel W. Calhoun, Conviction Without Imposition: A Response to Professor Greenawalt, 9 J.L. \& ReLiGion 289, 306 (1992) (emphasis added). See also Samuel W. Calhoun, Misreading the Judeo-Christian Tradition and the Law: A Response to Professor Smolin, 15 U. DAYTON L. REv. 383, 397-98 (1990) (discussing the "delusion" that right behavior can create favor with God). 
'perpetuates the 'cruel delusion,' at odds with the Christian Gospel, that righteous conduct is the road to a restored relationship with God." 195

As an evangelical Christian who has lived his entire life in the southern United States (specifically for me, Texas), where evangelical Christianity is culturally dominant, there is an obvious realization of the pervasiveness of this works-based moralism. It is perpetuated (especially in these parts, by the Religious Right) by many wellmeaning Christians who long to see a more righteous, more moral, and better life for all the citizenry, but I believe it has a devastating effect on the gospel message which ironically is the only means for the true conversion of culture. My personal experience of what happens when these arguments are made, whether in a church setting or a political setting, is further illustrated by Chandler:

One of my frustrations living in the Bible Belt is that the gospel and its ancillary truths have been so divorced from actual living that a lot of beautiful theology has become cliché. There is a sentimentalization of the faith that occurs when you sanitize the gospel of Christ crucified or sift it from the substance of the Christian religion. The result is a malleable Jesus, a tame Jesus. The result is, as Michael Spencer says, "a spirituality that has Jesus on the cover but not in the book." When we dilute or ditch the gospel, we end up with an evangelicalism featuring special appearances by Jesus but the denial of his power. ${ }^{176}$

When this sort of dilution of the gospel message occurs, "what you have are people that have been conformed to a pattern of religious behavior but not transformed by the Holy Spirit of God."

175. Samuel W. Calhoun, Misreading the Judeo-Christian Tradition and the Law: A Response to Professor Smolin, 15 U. DAYTon L. REV. 383, 397-98 (1990) (emphasis added). I should note that Professor Calhoun has engaged over the ensuing years in a very thoughtful development of his views on the propriety of Christian political argumentation in the public square and has now decided that such advocacy should not be discouraged, but rather that Christians should have an equal place at the table in any political debate. See Samuel W. Calhoun, May the President Appropriately Invoke God? Evaluating the Embryonic Stem Cell Vetoes, 10 RUTGers J.L. \& Religion 1 (2008); Samuel W. Calhoun, The Politics of Virtue: Is Abortion Debatable?, 16 J.L. \& RELIGION 405 (2001). Of course, I agree that there is a right of free speech to all citizens protected by the Constitution, but I am rather arguing about the propriety of such communication when considered from a theological perspective and possible ideals of restraint. Although we disagree on the desirability of making explicit appeals to Christian rhetoric in public political arguments, I am immensely grateful for Professor Calhoun's assistance in my thinking about these issues.

176. Chandler \& Wilson, supra note 60 , at 84 (quoting Michael Spencer, Mere Churchianity: Finding Your Way Back to Jesus-Shaped SpIRITUality 51 (2010); 2 Timothy 3:5 (ESV)).

177. $I d$. 
This should not be what Christians are after. We should desire to spread the correct message of the Christian gospel-that salvation is needed for sinful rebellion against God, and that it is only possible by faith in the provision of Christ's sacrifice on our behalf. Injecting law, or politics, into a discussion of the Christian faith only serves to send the wrong message:

Liberals [i.e., many on the Religious Left] want to make social justice the center. Fundamentalists [i.e., many on the Religious Right] want to make moral behavior the center. (Their motto is "Do, do, do," but the cross screams out "Done!") All of these things are good things, biblical things. But to make any of them the center of the Christian faith, the grounds of our hope, is to disregard the only power of salvation---the message of the cross. ${ }^{178}$

This is the wrong message; it is the wrong gospel. Jesus said that we Christians should spread the gospel news far and wide-in the Great Commission we are urged to go forth to all the world with the gospel message and its implications. ${ }^{179}$ But it should be the correct message. Paul gave strict warnings against misstating the correct gospel message, and condemned any who preach a contrary message. ${ }^{180}$ This is a sobering warning, and should cause Christians to earnestly desire to only communicate correct public messages about Christian truths.

Thus, the message could not be clearer. We Christians, as the church, should preach the correct gospel message to the world. Salvation is through faith in Christ alone, and not by works or law. When we communicate incorrectly we are hindering, rather than assisting, the cause of Christianity. Thus the correct evangelical Christian theology is actually to leave the secular, civil law out of it. Arguments about the law in our society should be made in the Rawlsian manner of public reason-overt reference to Christian principles should be left aside. This is not only out of adherence to principles of liberal democracy and respect for fellow citizens, but to avoid the danger of sending an incorrect theological message about the sacred gospel message of faith alone being the way to salvation. In our churches, in our neighborhoods, and in our culture generally we should preach faith in Christ, but in our political argumentation for coercive law we should argue in terms of public reason.

178. Id. at 69 .

179. Matthew 28:16-20 (ESV).

180. Galatians 1:8-9 (ESV). 


\section{Two Corroborating Observations}

My primary thesis is that evangelical Christians can fully comply with Rawlsian public reason in their political argumentation, and that when they instead attach the "Christian" label to their political advocacy, they not only violate the ideals of liberal democracy but they also tragically communicate an incorrect message about the Christian gospel and the way to find ultimate favor with God. I have a couple of other observations about the mixture of Christian political argumentation which serve to further buttress the point that such argumentation is inappropriate.

\section{The Infeasibility of Codifying all Christian Moral Precepts}

Aside from the from the fact that legislating "Christian" principles sends the wrong message about the evangelical Christian gospel of salvation by faith alone, codifying all biblical concepts of morality is completely unworkable in any event. Randall Balmer has noted that there is a tendency to only focus on a handful of "Christian issues" from the scriptures, while ignoring the rest. ${ }^{181}$ Thus, for instance, the Religious Right tends to focus on abortion and homosexuality as their key issues, while virtually ignoring issues of, say, divorce. ${ }^{182}$ And this is in spite of the fact that Jesus sternly said about divorce: "And I say to you: whoever divorces his wife, except for sexual immorality, and marries another, commits adultery." 183 And yet few in the evangelical Christian community are championing stricter laws for divorce in the United States, being instead content with the current state of "no-fault" divorce.

This is not to say that I would support such a move on the part of the Christian political community. No-fault divorces would seem to be the overwhelming democratic will of the citizenry, giving their overwhelming applicability in the United States. And this is in spite of the fact that allowing such divorces would appear to be strictly against the stern morality Jesus preached. The issue appears to concern a balancing of the desire for moral codes on the one hand, with some concession for realistic human ability to conduct behavior on the other. This concession to certain realistic human frailties was apparently a principle of the Old Testament theocratic Jewish state instituted by God himself. We know this because divorces had been more widely permitted by Mosaic law, and Jesus acknowledged this in his preaching

181. See Randall Balmer, Thy Kingdom Come: An Evangelical's Lament-How the Religious Right Distorts the FAITH AND THREATENS AmERICA 1-35 (2006).

182. See id.

183. Matthew 19:9(ESV). 
and explained why this had been allowed: "Because of your hardness of heart Moses allowed you to divorce your wives, but from the beginning it was not so." 184 Thus, even in a theocratic state instituted by God Himself, as a practical concession to some allowances for the imperfection of humans, God allowed the Israelites to divorce their spouses more than a perfect Christian morality would presuppose.

This is not to mention other types of extreme Christian morality which are conveniently left aside in the political argumentation by both the Religious Right and Left. For instance, Jesus stated that not only was murder a sin, but anyone who became angry with another was similarly guilty. ${ }^{185^{\prime}} \mathrm{He}$ also stated that not only was adultery a sin, but that anyone who looked at another woman with lust in his heart was similarly guilty. ${ }^{186} \mathrm{We}$ are told in the Ten Commandments that we should not covet, that we should not bear false witness (lie), that we should keep the Sabbath. ${ }^{187}$ Jesus said in the Sermon on the Mount that if anyone strikes you, to turn the other cheek to him as well. ${ }^{188}$ If anyone asks for your tunic, let him have your cloak, too. ${ }^{189}$ The rich man was told to sell everything he had and give it to the poor. ${ }^{190}$ No one, not even the most militantly political evangelical Christian, seriously believes that the above should be codified into public secular law. It is far too high of a moral standard to expect people to comply. This is why, at least in part, that Bill Stuntz and David Skeel wrote that Christian principles should result in a much more modest secular rule of law. ${ }^{191}$ With regard to God's moral standards on the one hand, and secular legislation on the other, they wrote: "The solution to this seeming inconsistency is the rule of two kinds of law: one for hearts and minds, and the other for code books and courtrooms. Only God's law is fit for the former purpose. Law that operates in the latter territories must have more humble ambitions." 192

\section{The Two Kingdoms}

My other corroborating observation is one that overlaps the other discussion to this point. Power and the Christian gospel are not an appropriate mix, at least not yet in this life. When Jesus was being

184. Id. 19:8.

185. Id. 5:21-22.

186. Id. $5: 27-28$.

187. Exodus 20:8, 14, 16-17 (ESV).

188. Matthew 5:39 (ESV).

189. Id. 5:40.

190. Id. 19:21.

191. See David A. Skeel, Jr. \& William J. Stuntz, Christianity and the (Modest) Rule of Law, 8 U. PA. J. Const. L. 809, 839 (2006).

192. Id. at 812 . 
questioned by Pilate, the Roman governor who would shortly thereafter sentence Jesus to death by crucifixion, he asked Jesus whether he was King of the Jews. ${ }^{193}$ Jesus responded: "My kingdom is not of this world. If my kingdom were of this world, my servants would have been fighting, that I might not be delivered over [to be crucified.] But my kingdom is not from the world." 194 Thus, Jesus can be read as saying that there are two kingdoms-one of the current world, and one presumably spiritual, eternal kingdom not of this world. In fact, the "two kingdoms" view has been prevalent throughout centuries of Christian thought. ${ }^{195}$ But the voices of the Religious Right and the Religious Left too frequently confuse the two kingdoms. The civil, secular rule of law is of course necessary to have an orderly society, and to keep life from being, according to Hobbes, "nasty, brutish and short." ${ }^{96}$ But in no way should it be confused with a divine, spiritual standard of holiness. To do so profanes that which is holy, and confuses the two kingdoms. ${ }^{197}$

That this was Jesus's view is further corroborated by at least one other exchange documented in the scriptural accounts of His earthly life. Jesus was asked by the Pharisees (the religious Jewish leaders of the day) whether it was right to pay taxes to Caesar (the secular political leader of the Roman government at the time). ${ }^{198}$ After noting that Caesar's image was on a coin, Jesus famously responded: "Render to Caesar the things that are Caesar's, and to God the things that are God's." 199 Although the meanings of this passage have been pondered for the millennia since Jesus' life, it appears obvious that Jesus is again alluding to the fact that are two planes or spheres of existence-an earthly political kingdom (Caesar's), and a spiritual kingdom (God's). One could easily map this onto the Rawlsian debate on religious arguments and apply it so that the Christian is counseled to "render unto Caesar what is Caesar's" (proper democratic participation in a liberal democracy under dictates of public reason), and "render unto God what is God's" (professed faith in Christ and subjection to God's ultimate

193. John 18:33 (ESV).

194. Id. 18:36 (emphasis added). It is also significant that, early in his ministry, Jesus rejected Satan's attempt to tempt him with earthly political power. Matthew 4:8-10 (ESV).

195. See, e.g., David Vandrunen, The Context of Natural Law: John Calvin's Doctrine of the Two Kingdoms, 46 OXFORD J. CHURCH \& ST. 503, 514 (2004).

196. Skeel \& Stuntz, supra note 191, at 815 ("Government is essential to avoid lives that are, in Hobbes' famous phrase, 'nasty, brutish, and short.") (quoting THOMAS HOBBES, LeviATHAN 96 (A.P. Maninich ed., Broadview Literary Texts 2002) (1651)).

197. See HUNTER, supra note 14, at 175 ("The tragedy is that in the name of resisting the internal deterioration of faith and the corruption of the world around them, many Christiansand Christian conservatives most significantly-unwittingly embrace some of the most corrosive aspects of the cultural disintegration they decry.").

198. Mark 12:13-14 (ESV).

199. Id. 12:17 (emphasis added). 
spiritual authority). This is corroborated further still by Paul's instruction to the Roman church to be subject to the civil authorities (i.e., the civil government), noting it had been instituted by God. ${ }^{200}$ This is an acknowledgment of the "kingdom of Caesar" Jesus was alluding to. The Christian faith and mere secular government are two separate planes of existence entirely, and we must not conflate the two profanes.

\section{CONCLUSION}

Overt Christian political argumentation conflates advocacy for law with advocacy for "Christian principles or values." The expressive effect is that agreeing with the law and later complying with the law, is tantamount to compliance with the "Christian" religion and will result in favor with God. John Rawls and others have argued that such religious argumentation is inappropriate in a liberal democracy. But there is a corroborating reason from within evangelical Christianity to refrain from such political argumentation. The arguments of the Religious Right and Left communicate behavior-based moralism, but this expresses a tragically mistaken view of the evangelical Christian gospel message. That message is that we can obtain divine favor by works (or law). "Human beings are natural-born moralists, and moralism is the most potent of all the false gospels." ${ }^{201}$ Moralism works is a false gospel because evangelical Christians universally profess that salvation and reconciliation with God comes only by faith alone in the provision of Christ's sacrifice in atonement for our sinful condition.

I wish to add, near my conclusion, that I am not arguing that Christian citizens in the United States do not have every right to come to their political decisions by making full use of their faculties, reason, and their belief in transcendent realities, including a view of what is ultimately the best conception of the good. Such a view may well include an unshakeable conviction in the justice or morality of any number of political issues or choices, based on a view of divine morality. Certainly, I could not possibly presume to argue that we are not all fully supported by our constitutional protections to engage in any such speech in this regard as we should choose. That is, legal rights to speak as the Religious Right and Left do are not what is at stake here.

Instead, I am arguing for a Christian communicatory ideal. I am arguing that as Christians, we should take very seriously the fact that in making public political "Christian" argumentation, we may be

200. Romans 13:1 (ESV).

201. Albert Mohler, Christian Values Cannot Save Anyone, (AlbertMohler.com, Sept. 11, 2012), http://www.albertmohler.com/2012/09/11/christian-values-cannot-save-anyone/ (emphasis added). 
misleading the public about the way in which they can obtain favor with God, to the tragic hindrance of the church's actual gospel mission. In doing so, such political advocates are also selectively choosing which Christian moral precepts to emphasize, they are engaging in arguably inappropriate judgment of select unbelievers by focusing on only a few "issue sins," and they are mistaking the two kingdoms Jesus clearly recognized during His ministry. Skeel and Stuntz are especially prescient here:

Christians could stand to learn the . . . lesson [that Christian moral precepts make for poor secular law]. The New Testament makes abundantly clear that law cannot save souls; salvation must come through other means and from another Source. In the apostle Paul's letters, law is not the mechanism of salvation; rather, law shows the need of it. Paul repeatedly warns Christians about the dangers of converting their faith into a moral code, just as Jesus condemned the Pharisees for doing the same thing to their own faith and thus weighing down the people with burdens too heavy to carry. One might expect professing Christians to be especially attuned to the dangers of legal moralism. Judging from contemporary culture-wars debates, we are not. The heart of the problem is a tendency to confuse God's law with man's. Those of us who believe in a divine moral law are regularly tempted to try to write that law into our much-less-than-divine code books. ${ }^{202}$

In short, Christian political advocates effectively communicate a reversed order of salvation and works, seemingly sending a message that works and law are a means to achieve reconciliation and favor with God. However, the scriptures teach that salvation is obtained by faith in Christ alone and not works. ${ }^{203}$ Evangelical Christians agree that good works (i.e., behavior pleasing to God) do follow as one increasing consequence of faith, but they are properly seen as a result of such faith and not a cause of it. ${ }^{204}$ To try to reverse the scriptural order of these is a fool's errand, and causes unneeded consternation in the political processes of a liberal democratic republic such as ours, not to mention obscuring the very gospel message that Christ gave to the church. As Christians, we know that in many, if not most, instances the gospel will be offensive to those who do not believe, ${ }^{205}$ but as Christians we should also take great care to make sure when it offends, that it does so for the

202. Skeel \& Stuntz, supra note 191, at 831-32 (emphasis added).

203. Ephesians 2:8 (ESV); Romans 3:28 (ESV); Galatians 2:16 (ESV).

204. James 2:14-18 (ESV); Galatians 3:5 (ESV); Philippians 2:13 (ESV); Romans 6:22 (ESV).

205. See Romans 9:33 (ESV). 
right reason and not by misusing the "Christian" label for political purposes. 